\title{
The Perspective of Indonesian Law on E-Commerce: Validity, Liability and Dispute Settlement
}

\author{
Ghansham Anand ${ }^{*}$, Lintang Yudhantaka** Manik Lingkar Katulistiwi ${ }^{* * *}$ \\ DOI: https://doi.org/10.22304/pjih.v7n3.a3
}

Submitted: September 21, 2020 | Accepted: December 8, 2020

\begin{abstract}
In the era of globalization, the fast development of technology enables people to complete almost all activities with technological assistance. One of the activities is commerce. Commercial activity by means of electronic media is called e-commerce. Like ordinary commerce, e-commerce requires contract to order rights and obligations of parties involving in transaction. This study aims to discuss and to elaborate legal construction of e-commerce in addition to the liability of merchant for any loss resulted. In practice, only few consumers fully understand contents of contract. Many of them experience losses either because of their negligence in understanding contract or the fraudulent actions of business actors. This study employed legal research method with conceptual and statute approach. The study reveals that e-commerce is a form of e-contract. In addition, e-commerce is constructed as sales and purchase agreement since it arranges subjects, objects, and primary obligations of the pertinent parties. On the subject of liability of merchants, they must be liable if they were revealed violating contract and taking their consumers into loss.
\end{abstract}

Keywords: e-commerce, liability, sale and purchase agreement.

\section{E-Commerce dalam Perspektif Hukum Indonesia: Keabsahan, Tanggung Gugat dan Penyelesaian Sengketa}

\begin{abstract}
Abstrak
Pada era globalisasi ini, perkembangan teknologi yang begitu pesat memungkinkan semua kegiatan dilakukan dengan menggunakan bantuan teknologi, termasuk kegiatan perdagangan. Kegiatan perdagangan tersebut menggunakan media elektronik yang biasa disebut dengan e-commerce (electronic commerce). Seperti kegiatan perdagangan pada umumnya, kontrak juga dibutuhkan dalam e-commerce untuk mengatur hak dan kewajiban pada pihak dalam melakukan transaksi. Tujuan dari penelitian ini adalah untuk mendiskusikan serta mengelaborasi tentang konstruksi hukum dalam kegiatan e-commerce dan tanggung gugat pelaku usaha terhadap kerugian yang telah ditimbulkan. Dalam praktiknya sangat jarang bagi para pihak untuk memahami isi kontrak, terutama konsumen, sehingga banyak diantara mereka yang mengalami kerugian baik itu diakibatkan karena kelalaiannya dalam memahami kontrak maupun tindakan pelaku usaha yang curang.
\end{abstract}

PADJADJARAN Journal of Law Vol. 7 Number 3 Year 2020 [ISSN 2460-1543] [ISSN 2442-9325]

Lecturer of the Faculty of Law, Universitas Airlangga, Jl. Dharmawangsa Dalam Selatan, Airlangga, Surabaya, S.H. (Universitas Tadulako), M.H., Dr. (Universitas Airlangga), ghansam@fh.unair.ac.id

** Lecturer of the Faculty of Law, Universitas Pembangunan Nasional "Veteran” Jawa Timur, Jl. Rungkut Madya No. 1, Surabaya, S.H., M.H. (Universitas Airlangga), lintang.ih@upnjatim.ac.id

*** Student of Master's Program in Notarial Law of the Faculty of Law, Universitas Narotama, Jl. Arief Rachman Hakim 51, Sukolilo, Surabaya, S.H. (Sekolah Tinggi Ilmu Hukum Zainul Hasan), sayamaniq@gmail.com 
Penelitian ini menggunakan metode penelitian hukum dengan pendekatan konseptual dan peraturan perundang-undangan. Hasil dari penelitian ini menunjukkan bahwa e-commerce juga termasuk ke dalam kontrak elektronik (e-contract) dan e-commerce juga dikonstruksikan sebagai perjanjian jual beli karena pengaturan mengenai subjek, objek serta hak dan kewajiban pokoknya berasal dari para pihak. Dalam kaitannya dengan tanggung gugat pelaku usaha (penjual), ia bertanggung gugat apabila terbukti melanggar perjanjian yang telah disepakati dan menimbulkan kerugian bagi konsumen.

Kata kunci: e-commerce, perjanjian jual beli, tanggung gugat.

\section{A. Introduction}

Technological developments in the era of globalization allow trading activities to be practiced through electronic media. It is often referred to as electronic commerce (e-commerce). ${ }^{1}$ Like trading in general, e-commerce requires a contract containing rights and obligations of the involved parties. The contract is known as electronic contracts (e-contracts).

Makarim defines electronic contract or online contract as an agreement or legal relationship that is carried out electronically by combining network from a computer-based information system with a communication system based on telecommunication-based networks and services. They all are facilitated by a global computer internet (network of network). ${ }^{2}$ In origins, trade is defined as activity of sellers and buyers. However, in electronic commerce, sellers and buyers do not meet physically. All process of a contract from bid to agreement takes place in electronic media.

Indonesia has recognized the existence of an electronic contract in Article 18 paragraph (1) of the Law Number 11 of 2008 on Electronic Information and Transactions (EIT Law) as amended by the Law Number 19 of 2016 on the Amendments to the Law Number 11 of 2008 on Electronic Information and Transactions. The legalization of electronic agreement makes the electronic agreement in Indonesia considered a legal and binding agreement for the parties.

According to Laudon \& Laudon, e-commerce is a process of buying and selling products electronically by consumers and from company to company with computers as the intermediary of the business transactions. ${ }^{3}$ E-commerce is useful to reduce administrative costs and business process cycle times and to improve relationships with both business partners and customers. ${ }^{4}$

Yahya Ahmad Zein, Kontrak Elektronik \& Penyelesaian Sengketa Bisnis E-Commerce, Bandung: Mandar Maju, 2009, pp. 27-31.

2 Edmon Makarim, Pengantar Hukum Telematika: Suatu Kompilasi Kajian, Jakarta: Raja Grafindo Persada, 2005, pp. 254-255.

3 Kenneth C. Laudon and Jane P. Laudon, Management Information Systems: Managing the Digital Firm, 11th Edition, Edinburgh Gate: Pearson Education Limited, 2010, p. 373.

4 Mahir Pradana, "Klasifikasi Jenis-Jenis Bisnis E-Commerce di Indonesia", Jurnal Neo-bis, Vol. 9, No. 2, 2015, p. 2. 
The development of e-commerce in Indonesia is very fast. Various e-commerce businesses have sprung up offering the convenience of buying and selling transactions. The e-commerce business can be classified as, among others, online stores, marketplaces, and e-commerce. ${ }^{5}$ Online shop is an online shopping system where buyers can ask prices, or any questions related to products to sellers directly. Second, marketplace is a business model in which the website is concerned not only to help promote merchandise but also to facilitate online money transactions. In this online shopping system, a website provides plots or places for sellers to sell their products. Each product contained on the website has been given specifications and an explanation of the product's condition. Buyers can immediately click the "buy" button and transfer money equal to the listed price. Third, e-commerce is a business model that allows companies and individuals to buy and sell goods over the internet. Buyer receives offers from seller and must pay attention to the terms given. Buyer must fulfill several stages determined by seller before making payment. After all these steps, buyer can make payments. For additional information, there is no bargaining and prices are fixed.

A new development in Indonesia indicates some issues related to consumer protection. Therefore, the Law Number 8 of 1999 on Consumer Protection (Consumer Protection Law) is established to cover the issue. In the past, business actor was seen as a very instrumental in the development of state's economy and received more attention. Now, consumer protection has received more attention in line with the increasing protection of human rights. Consumers need to receive greater protection. ${ }^{6}$ For instance, a buyer wants to buy an item online. Then, the buyer makes payment by transferring money to an online shop's account. However, the item received by the buyer is different from the one selected. In practice, there are buyers who do not receive items they bought at all. A buyer bought hard drives at Tokopedia (one of Indonesian largest marketplace), to be precise at a store with the account name "Lioe Kon Tjen". ${ }^{7}$ However, he does not get a hard drive but only an image. Obviously, such practice is very detrimental to consumers.

According to Kristiyanti, if a consumer feels that the quantity and quality of the goods and/or services they consume is not in accordance with the exchange rate provided, the consumer is entitled to receive appropriate compensation. The type and amount of compensation must be in accordance with the applicable provisions or on the agreement of each party. To get compensation, buyer can submit a request to seller directly. If the request submitted by the buyer does not receive a proper response from the seller, then the buyer is entitled to legal solutions,

Gita Anggaranie, "Klasifikasi Bisnis e-Commerce", https://supplychainindonesia.com/klasifikasi-bisnis-ecommerce/, accessed on September 2020.

Celina Tri Siwi Kristiyanti, Hukum Perlindungan Konsumen, Jakarta: Sinar Grafika, 2009, p. 38.

Rivki, "Kasus Jual-Beli Online Gambar Hard Disk, Ahli Hukum: Ada Unsur Menipu", https://news.detik.com/berita/d-4302473/kasus-jual-beli-online-gambar-hard-disk-ahli-hukum-ada-unsurmenipu, accessed on October 2020. 
including advocacy. In other words, consumers have the right to demand legal responsibility from parties responsible. ${ }^{8}$ Based on the description, this study examined the issues related to legal construction of buying and selling through electronic media and the liability of business actors for losses suffered by consumers.

\section{B. Legal Construction of Electronic Transaction}

\section{History of E-Commerce}

In 1962, Licklider conducted a study on the concept of networking. In 1970, the Electronic Fund Transfer (EFT) was emerged, and the Electronic Data Interchange (EDI) expanded from financial transactions to other transactions. In 1994, electronic banners were used initially for promotional and advertising purposes on websites. Four years later, secured protocol such as https (Hypertext Transfer Protocol Secure) is started to be used widely. For the period of 1998-2000, many businesses in the United States and Europe developed trading websites. ${ }^{9}$

When information technology develops very rapidly, the need for the internet is one of the primary needs of society, especially in urban areas. Utilization of the internet is considered a necessity for all levels of society, including businesspeople. Businesspeople at all levels do not waste the opportunity to sell goods and services to consumers by means of electronic media. Businesspeople must quickly adapt to technology because manual businesses are far behind in the process of delivering information and handing over goods/services. In the business world, the speed and accuracy of the process of conveying information and transactions will determine success. This principle is firmly held by online businesspeople. The process of buying and selling through electronic media, the e-commerce, consists of the processes of buying and selling, transferring, or exchanging products, services and information by use of the internet network. ${ }^{10}$

\section{The Validity of Agreement in E-Commerce}

The validity of electronic transactions contained in the electronic contract binds on the parties (Article 18 paragraph 1 of the EIT Law). A transaction is a legal act that involves two parties who need each other in matters that have a certain economic value and are realized through an agreement called 'a contract'. ${ }^{11}$ The legal relationship arising from electronic business transactions that are contained in an electronic contract is a legal relationship that originates from the agreement. Hence, by analogy, the contract law arrangement in the Indonesian Civil Code or Burgerlijk Wetboek (BW), specifically in Book III on Engagement, can be enforced as

\footnotetext{
Celina Tri Siwi Kristiyanti, loc.cit.

Mudakir Iskandar Syah, Hukum Bisnis Online Era Digital, Jakarta: Campustaka, 2018, p. 15.

Ibid.

Hasanuddin Rahman, Contract Drafting Seri Keterampilan Merancang Kontrak Bisnis, Bandung: Citra Aditya Bakti, 2003, p. 2.
} 
a rule of law in accordance with the lex generalis principle for electronics arrangement. $^{12}$

Article 1338 of the BW contains an imperative provision that a legally valid contract (vide Article $1320 \mathrm{BW}$ ) binds parties who make the contract provided that the performance conditions in the contract do not conflict with positive legal rules, public order, and morals. In connection with the legal terms of a contract according to Article 1320 and its enforceability to electronic contracts, the question arises how to ensure that the first condition, namely their agreement that binds themselves can be fulfilled in an electronic contract based on electronic business transactions or e-commerce. ${ }^{13}$ Likewise, second, third, and fourth conditions also need to be considered in relation to this electronic contract.

To be considered as legally valid, an agreement must meet the requirements of the validity of the agreement stipulated in Article 1320 of the BW, they are:

a. agreement on they who bind themselves (agreement/toestemming);

b. capacity to make an agreement (competence/bekwaamheid);

c. toward certain object (certain objects/een bepaald onderwerp); and

d. lawful cause (cause/oorzaak).

The first and the second conditions are subjective terms because they concern people or subjects who enter into agreement. On the other hand, the third and the fourth terms are objective conditions because they are about the agreement itself or the object of the legal act that is committed. ${ }^{14}$ Failure to fulfill one or more of the terms may generate the following consequences: ${ }^{15}$

a. Non-existence, this means there is no agreement.

b. Vernietigbaar, this means the contract is voidable, if the contract was born because of a defect of will (wilsgebreke) or because of incompetence (onbekwaamheid) - (Article 1320 of the BW, the first and second terms). It means that this is related to a subjective element, so that the contract can be canceled.

c. Nietig, this means the contract is considered to be null and void, if there is an agreement that does not meet the requirements of a certain object or the cause is not allowed (Article 1320 of the BW, the third and fourth conditions). This condition is related to the objective elements of contract (certain object and lawful cause), so that the agreement is null and void.

The following explains each of the terms stipulated in Article 1320 that are related to e-commerce contracts.

\footnotetext{
Muhammad Syaifuddin, Hukum Kontrak, Bandung: Mandar Maju, 2012, p. 266.

Ibid., p. 256.

Subekti, Hukum Perjanjian, Jakarta: Intermasa, 2014, p. 17.

Agus Yudha Hernoko, Hukum Perjanjian Asas Proporsionalitas dalam Kontrak Komersial, Jakarta: Kencana Prenadamedia Group, 2014, p. 160.
} 


\section{a. Agreement on they who bind themselves (agreement/toestemming)}

Element of agreement in e-commerce is determined by buyers' access and acceptance. In other words, buyer agrees on a legal relationship. E-commerce is considered as a standard contract because all offers, and terms of purchase are listed. Buyer has choices to agree or not. Buyer's agreement becomes the basis for equal will of parties that eventually generates electronic contract.

\section{b. Ability to make an agreement (competence/bekwaamheid)}

Ability to make an engagement refers to legally competent person. The person must be matured according to the law. The person is at least 18-years old, has been married, and is not under interdiction. The element of competence in e-commerce is complicated, considering everyone (despite the age) can carry out electronic transactions in accordance with Article 2 of the EIT Law. Based on this provision, children, or minors, can do e-commerce without having to meet the subjective requirements in Article 1320 of the BW. Such contract can be canceled through someone who files cancellation in court.

\section{c. Toward certain object (certain objects/een bepaald onderwerp)}

A certain object refers to trading object that must be determinable. Online products are contained in the form of images or photos accompanied by product specifications. However, there is no guarantee that the product will be sent to the buyer even after a payment is made.

\section{d. Permissible cause (cause/oorzaak).}

Permissible cause refers to any goods and services that are not against law, decency, and public interest. In e-commerce, both seller and buyer must ensure that both parties carry out buying and selling transactions in good faith. If these conditions are not met, the electronic contract is null and void.

Based on the above explanation, e-commerce is legally valid as long as it complies with Article 1320 of the BW. Applies equally to e-commerce transaction, the first and second requirements are subjective terms because they are attached to the parties involved in e-commerce. On the other hand, third and fourth requirements are the objective requirements because they are attached to objects of commerce. If the first and/or second conditions are not fulfilled, the interested party can cancel the electronic contract within five years in accordance with Article 1454 of the BW.

Apart of the provisions of Article 1320 of the BW, it is also necessary to pay attention to the Principle of Proportionality. Hernoko says that the principle of proportionality is more dominant in commercial contracts. The principle of proportionality does not question the equality of mathematical results, but it rather emphasizes the proportion of the distribution of rights and obligations between parties to be fair. ${ }^{16}$ Regarding e-commerce contracts, it is also necessary to consider

16 Agus Yudha Hernoko, op.cit., p. 89. 
containing contract clauses proportionally to produce a fair contract. Fair in the contract does not mean that it must be equal; it must be in proportion.

To determine that an agreement has been fulfilled and the contract is considered to have entered into force, there can be an analysis based on contract law theories as follows.

\section{a. Theory of offer and acceptance}

The basic theory of the agreement of the will is the theory of "offer and acceptance". In principle, a new agreement happens after an offer from one of the parties is accepted. Subsequently, the other party also accepts it. This theory is recognized in every legal system, even though the development of this theory is mostly carried out in states with the common law legal system.

b. Theory of Willing (Wills Theorie)

This theory teaches that the agreement happens when the will of the recipient is expressed, for example by writing a letter.

\section{c. Theory of Delivery (Verzend Theorie)}

According to this theory, the agreement happens when the party receiving the offer sends the declared will. In other words, the agreement happens when the party receiving a contract offer sends the reply letter. It is because, after the time of delivery, the sender of the reply has lost power over the letter.

\section{d. Theory of Knowledge (Vernemings Theorie)}

This theory covers the knowledge of the offering party. According to this theory, an agreement happens when the person who offers it knows that the other party has approved the offer. Therefore, the offering party should already know that the offer is accepted.

\section{e. Theory of Trust (Vertrouwens Theorie)}

This theory argues that agreement is reached when a statement of willing is (objectively) deserve to be accepted by the offerer.

\section{f. Theory of Mailbox (Mailbox Theorie)}

This theory argues that the acceptance of an offer -just so a contract is considered made- happens when the letter of acceptance is put into mailbox.

\section{g. Theory of Statement (Uiting Theorie)}

This theory defines that an agreement of willing happens when the acceptor of an offer has prepared a response stating that he/she accepts the offering.

\section{h. Theory of Notion}

Pitlo adopts this subjective theory. According to the theory, when there is an agreement, then there is a contract. Suppose the accepting party has sent a response letter and can reasonably suspect that the other party (the offering party) knows the contents of the letter. ${ }^{17}$

17 Mariam Darus Badrulzaman, Kompilasi Hukum Perikatan, Bandung: Citra Aditya Bakti, 2001, p. 68. 
It is also necessary to pay attention to cancellation of agreement made by the parties because of a defect of will. Based on Article 1321 of the BW, an agreement made by parties becomes invalid if it is proven that the agreement occurred because of a defect of will. The defect can be in the form of delusion (dwaling), coercion (dwang), or deception (bedrog). Over time, the types of defects are not only as stated in Article 1321 of the BW. There is one more new type of defect, the abuse of circumstances (misbruik van omstandigheden). ${ }^{18}$ It can be concluded that defects of will include four of aforementioned circumstances. If the four circumstances exist in the making of an agreement, the agreement can be canceled, and the contract becomes null and void.

Among the aforementioned theories, Indonesia adheres to the theory of offer and acceptance. This is reflected in Article 20 paragraph (1) and (2) of the EIT Law which states that

"(1) Unless the parties specify otherwise, an electronic transaction happens when the transaction offer by sender has been received and approved by recipient.

(2) Approval of Electronic Transaction offers as intended in paragraph (1) of the article must be made with an electronic acceptance statement."

With the increasing number of electronic transactions, legal instrument is needed to regulate them. Therefore, people involved in electronic transactions, especially consumers, will get legal protection for every electronic transaction they do. Likewise, data/documents made electronically (paperless document) also require definite legal force, considering that so far, documents/deeds are only considered valid if they are written on paper (black on white). In overcoming the above problems, the legal provisions contained in BW can still be applied to electronic buying and selling transactions. Article 1457 of the BW states that "sale and purchase is an agreement whereby one party binds himself to deliver an object and the other party to pay the price promised". It can be concluded that the essential elements of buying and selling are the existence of goods and prices with regard to rights and obligations; in this case, the seller's obligation is to deliver the goods and have the right to receive payment. In the intervening time, buyer has an obligation to pay and is entitled to acquire goods. ${ }^{19}$

As previously explained, the validity of agreement in Indonesia is regulated in Article 1320 of the BW. The four terms for the validity of this agreement also automatically apply to the sale and purchase agreement in electronic transactions. Article 46 of the Government Regulation Number 71 of 2019 on the

\footnotetext{
18 Agus Satory, "Perjanjian Baku dan Perlindungan Konsumen dalam Transaksi Bisnis Sektor Jasa Keuangan: Penerapan dan Implementasinya di Indonesia", Padjadjaran Jurnal Ilmu Hukum, Vol. 2, No. 2, 2015, p. 276.

19 Lintang Yudhantaka and Ninis Nugraheni, "The Concept of Authorization (Bezit) in Sales and Purchase Transactions of Virtual Property", Yustisia, Vol. 8, No. 1, 2019, p. 84.
} 
Implementation of Electronic Systems and Transactions (Government Regulation 71 of 2019) contains the following.

"(1) Electronic transaction can be carried out based on electronic contracts or other contractual forms as a form of parties' agreement.

(2) Electronic Contracts are considered valid if:

a. there is an agreement between the parties.

b. it is carried out by a capable legal subject or authorized to represent in accordance with the provisions of laws and regulations.

c. there are certain things; and

d. the object of the transaction must not conflict with statutory regulations, morality, and public order."

In addition, there are several additional requirements in Article 47 of the Government Regulation 71 of 2019 as follows. ${ }^{20}$

“(1) Electronic Contracts and other contractual forms as intended in Article 46 paragraph (1) addressed to Indonesian residents must be made in Indonesian.

(2) Electronic contracts made with standard clauses must comply with the provisions regarding standard clauses as regulated in the statutory regulations.

(3) Electronic Contract shall contain at least:

a. identity of parties;

b. objects and its specifications;

c. electronic transaction requirements;

d. prices and fees;

e. procedures in the event of a cancellation by parties;

$f$. provisions that give the aggrieved party the right to return the goods and/or request a product replacement if there is a hidden defect; and

g. options of legal settlement for electronic transaction."

The promulgation of the EIT Law is a concrete form of the Indonesian Government to be proactive and responsive in national development as a continuous process. The Government must always be responsive to various dynamics within society, especially to fill the law on the development and advancement of information technology issues. ${ }^{21}$

\footnotetext{
20 Suwari Akhmaddhian and Asri Agustiwi, "Perlindungan Hukum Terhadap Konsumen dalam Transaksi Jual Beli Secara Elektronik di Indonesia", Jurnal Unifikasi, Vol. 3, No. 2, 2016, p. 46.

21 Ibid., p. 49.
} 


\section{Parties of Electronic Transaction}

E-commerce transactions involve several parties, directly or indirectly, based on the complexity of the transactions, despite the transaction processes are full or partial. Full transaction means the whole process, from the beginning until the payment. Mansur and Gultom identify parties involved in e-commerce transactions as follows.

a. Sellers, or merchants, or business actors are companies/producers that offer their products through the internet. To become a merchant, one must have and register their merchant account at a bank. Then, the merchant can receive payments from customers using credit cards.

b. Consumers or card holders are people who want to obtain goods or services by means of online purchases. Consumer shopping on the internet may be an individual or a company. If the consumer is an individual, the e-commerce transactions must concern the payment system, whether the payment use a credit card or cash. This is important to know, considering that many consumers are not credit card holders. Credit card holder is a person whose name is printed on the credit card issued by the issuer based on a formal agreement. ${ }^{22}$

Generally, in buying and selling transactions, parties only consist of business actors/sellers and consumers/buyers. In addition to these parties, other parties involve indirectly, for instance an expedition company. Expedition is required in ecommerce because sellers and buyers do not meet physically.

Business actor has the right to obtain payment that has been agreed upon with consumers for offered products. Apart from the right, business actor has an obligation to send product that has been paid by consumer. If a business actor makes default, the business actor must compensate consumer's losses. Rights and obligations arise after the agreement between consumer and business actor is made. Based on the agreement, the business actor has the right to get payment and the consumer has the obligation to pay. The business actor also has the obligation to deliver goods after the consumer fulfills the payment. ${ }^{23}$

\section{Comparison of Conventional Transaction and E-Commerce}

Conventional transaction and e-commerce are different. The following table compares conventional transaction and e-commerce.

Table 1. Comparison of Conventional Transaction and E-Commerce

\footnotetext{
22 Dikdik M. Arief Mansur and Elisatris Gultom, Cyber Law (Aspek Hukum Teknologi Informasi), Bandung: Refika Aditama, 2005, p. 152.

23 Enni Soerjati Priowirjanto, "Pengaturan Transaksi Elektronik dan Pelaksanaannya di Indonesia Dikaitkan dengan Perlindungan E-Konsumen", Padjadjaran Jurnal Ilmu Hukum, Vol. 1, No. 2, 2014, p. 297.
} 


\begin{tabular}{|c|c|c|}
\hline No. & Conventional Transaction & E-Commerce \\
\hline 1. & $\begin{array}{l}\text { Article } 1320 \text { of the Civil Code requires an } \\
\text { agreement of parties having } \\
\text { competence. Conventional transaction } \\
\text { has no party representing the sale and } \\
\text { purchase agreement. }\end{array}$ & $\begin{array}{l}\text { Article } 46 \text { paragraph (2) of the } \\
\text { Government Regulation Number } 71 \text { of } \\
2019 \text { regulates legal requirements of } \\
\text { online transaction. The subjective } \\
\text { requirement is an agreement of the } \\
\text { parties, whose are competent legal } \\
\text { subjects authorized to represent based } \\
\text { on the legislation. }\end{array}$ \\
\hline 2. & $\begin{array}{l}\text { Business actors must have a high capital } \\
\text { to set up a conventional shop. }\end{array}$ & $\begin{array}{l}\text { Business actors have relatively low } \\
\text { capital. In some cases, there can be no } \\
\text { capital at all, free. }\end{array}$ \\
\hline 3. & $\begin{array}{l}\text { Buyers can observe the physical } \\
\text { condition of product. They can try to feel } \\
\text { the product. They can check whether } \\
\text { there is any damage to the desired } \\
\text { products. }\end{array}$ & $\begin{array}{l}\text { The offered items can only be seen in } \\
\text { pictures representing the physical } \\
\text { product. Therefore, buyers cannot try } \\
\text { and make sure whether there is damage } \\
\text { to the products. }\end{array}$ \\
\hline 4. & Sellers and buyers head face to face. & $\begin{array}{l}\text { Processes and interactions between } \\
\text { sellers and buyers are carried out only } \\
\text { through the internet. }\end{array}$ \\
\hline 5. & $\begin{array}{l}\text { The form of the transaction does not last } \\
\text { for } 24 \text { hours. Therefore, buyer has a } \\
\text { limited time. }\end{array}$ & $\begin{array}{l}\text { The transaction model lasts } 24 \text { hours } \\
\text { without any time limit. Buyers can make } \\
\text { transactions anytime and anywhere }\end{array}$ \\
\hline 6. & $\begin{array}{l}\text { The marketing reaches a limited number } \\
\text { of prospective consumers. }\end{array}$ & $\begin{array}{l}\text { The marketing reaches very broad } \\
\text { prospective consumers. }\end{array}$ \\
\hline 7. & $\begin{array}{l}\text { Buyers get information about the } \\
\text { product during the transaction process }\end{array}$ & $\begin{array}{l}\text { Buyers get information about product } \\
\text { without having to meet face to face. }\end{array}$ \\
\hline 8. & $\begin{array}{l}\text { Buyer does not hesitate with the product } \\
\text { to be purchased and does not hesitate in } \\
\text { making transaction because buyer can } \\
\text { see the product and meet the seller face } \\
\text { to face. }\end{array}$ & $\begin{array}{l}\text { Buyer may have a doubt since the } \\
\text { transaction process must be based on } \\
\text { trust. Buyer does not meet the seller } \\
\text { directly and buyer can only trust a } \\
\text { product based on the listed information. }\end{array}$ \\
\hline 9. & $\begin{array}{l}\text { The agreement was resulted from direct } \\
\text { communication between the two parties. }\end{array}$ & $\begin{array}{l}\text { The agreement was resulted after buyer } \\
\text { clicks yes panel on website page and } \\
\text { agrees to the listed terms offered by } \\
\text { seller. }\end{array}$ \\
\hline
\end{tabular}

\section{Liability of Business Actor following Consumers' Loss}

\section{Principle of Liability}

When a party neglects its obligations, it causes losses to the other party. The party causing the loss must be held accountable for the committed actions. This accountability is a form of liability of the party causing the loss. The Black's Law Dictionary explains the definition of liability as "the quality, state, or condition of 
being legally obligated or accountable; legal responsibility to another or to society, enforceable by civil remedy or criminal punishment". ${ }^{24}$

Common definition of liability covers the same thing. According to Marzuki, ${ }^{25}$ liability is a specific form of responsibility. Liability refers to the position of a person or legal entity that has the legal obligation to pay some form of compensation or compensation after a legal event or legal action. Furthermore, the term liability also falls within the scope of civil society.

\section{Implementation of the Exoneration Clause in the Consumer Agreement}

An agreement appears based on the principle of contract freedom between two parties who have an equal position and both parties try to reach an agreement through a process of negotiation between them. However, nowadays there is a tendency that many agreements in business transactions are carried out not through a balanced negotiation process between parties. For instance, one party has prepared a standard condition of an agreement form and the other party chooses either agree or disagree. Such agreement is called a standard agreement. ${ }^{26}$

Badrulzaman defines it as an agreement that standardized exoneration requirements are standardized and outlined with the following characteristics: ${ }^{27}$

a. The contents are determined unilaterally by creditor whose position is relatively stronger than debtor.

b. The debtor does not determine the contents of the agreement at all.

c. Driven by their needs, debtor is forced to accept the agreement.

d. The form is written.

e. The agreement is prepared previously in bulk or individually.

Furthermore, Sjahdeini explains that standard agreement is an agreement in which user has standardized almost all of the clauses. The other party does not have the opportunity to negotiate or request changes. Only a few things have not been standardized, for example type, price, color, quantity, place, time, and several other specific things of the object. ${ }^{28}$

The terms usually cause bargaining position of consumer in standard contracts is no longer equal to that of producer or seller. Consumers can only accept or reject the contents of contract as a whole, not partially. ${ }^{29}$ The use of standard agreement in business world is commonplace. However, the use of standard agreement is not without legal problems when it is related to the four terms of the legality of the

\footnotetext{
Bryan A. Garner, Black's Law Dictionary, 10th Edition, St. Paul-Minnessota: Thomson Reuters, 2014, p. 1053. Peter Mahmud Marzuki, Pengantar Ilmu Hukum, Jakarta: Kencana Prenada Media, 2008, p. 258.

Agus Satory, op.cit., p. 273.

Mariam Darus Badrulzaman, Aneka Hukum Bisnis, Revised Edition, Bandung: Alumni, 2014, p. 45.

Sutan Remy Sjahdeini, Kebebasan Berkontrak dan Perlindungan yang Seimbang bagi Para Pihak dalam Perjanjian Kredit Bank di Indonesia, Jakarta: Pustaka Utama Grafiti, 2009, p. 66.

29 Moh. Ali and Agus Yudha Hernoko, "Characteristics of Party Autonomy in a Transnational Electronic Consumer Contract”, Yuridika, Vol. 35, No. 1, 2020, p. 65.
} 
agreement. One of which is "agreement by those who bind themselves" and its relationship with the principle of freedom of contract. The problem then arises whether the agreement and the principle of contract freedom, which is the basis of the agreement, are still fulfilled in the standard agreement.

The imbalance in contract process can be seen in the contract's clauses, especially in standard form contract containing biased clauses. Many parties can agree on biased contract of electronic transaction by simply reading the text without a complete understanding of the business process. Therefore, it raises problems regarding contract freedom and balance for the parties. Hernoko is of the opinion that the purpose of formulating a commercial contract is not to sharpen differences and impose a will but it is precisely to create cooperation based on an agreement. It must comply with the principles of business ethics and prevailing contract law principles. This commercial contract emphasizes the aspects of respect for partnerships and continuity of a business, not to differentiate, let alone impose the will on other parties. ${ }^{30}$

According to Article 1338 of the BW,

"all agreements made legally shall be valid as law for those who make them. The agreement cannot be withdrawn other than by the agreement of two parties, or for reasons determined by law. The agreement must be executed in good faith".

Based on the article, an agreement has legal consequences as a binding law for the parties. Article 1 number (10) of the Consumer Protection Law states

"standard clauses are any rules or conditions and requirements that have been prepared and determined unilaterally by business actor as outlined in a document and/or binding agreement and must be fulfilled by consumers."

The provisions regarding this standard clause are regulated in Chapter $\mathrm{V}$ on the inclusion of a standard clause consisting only one article, Article 18. This article regulates two types of prohibitions that are imposed on business actors who propose a standard agreement. Article 18 Paragraph (1) of the Consumer Protection Law regulates the prohibition of inclusion of standard clauses; and Article 18 Paragraph (2) of the Law regulates the form as well as the writing of prohibited standard agreements.

According to Article 18 Paragraph (1) of the Consumer Protection Law, in offering goods and/or services intended for trading, business actors are prohibited from making or attaching standard clauses to each document/or agreement if the agreement:

a. states the transfer of responsibility of business actors;

$30 \quad$ Agus Yudha Hernoko, op.cit., p. 3. 
b. states that business actors have the right to refuse the return of goods purchased by consumers;

c. states that business actors have the right to refuse the return of money paid for goods and/or services purchased by consumers;

d. states the granting of power from consumers to business actors either directly to take any unilateral actions related to goods purchased by consumers in installments;

e. regulates the matter of proof of the loss of use of goods or use of services purchased by consumers;

f. gives business actors the right to reduce the benefits of services or reduce the assets of consumers who are the object of sale and purchase of services;

g. states the consumer's submission to regulations in the form of new, additional, advanced and/or further amendments made unilaterally by the business actor during the period when the consumer has utilized the service purchased; and

h. states that consumers authorize business actors to impose guarantee rights on goods purchased by consumers in installments.

Furthermore, Article 18 paragraph (2) of the Consumer Protection Law explains that business actors are prohibited from including standard clauses whose location and shape are difficult to see or cannot be read clearly, or whose disclosure is difficult to understand. Violation on Article 18 Paragraph (1) and (2) and Article 18 Paragraph (3) of the law states such standard clause is deemed to have never existed and is not binding on the parties. In other words, they are null and void. Due to the cancellation, Article 18 Paragraph (4) of the Law requires business actors to adjust standard clauses that are contrary to this law.

The Consumer Protection Law does not prohibit business actors from making a standard agreement containing standard clauses on an agreement as long as the standard agreement does not include provisions as prohibited in Article 18 paragraph (1) and is not in the form as prohibited in Article 18 paragraph (2) of the law.

\section{Problems of E-Commerce}

Several obstacles often arise in electronic transactions are as follows:

\section{a. Competence of the subjects}

Competence in e-commerce is reviewed from the age limit of proficiency in accordance with Article 47 of the Law Number 1 of 1974 on Marriage, namely 18 years old. According to Article 1330 of the BW, parties that are incapable to make agreements are people who are not yet mature and/ or under interdiction. In electronic transactions, it is quite difficult to determine a person's competence. This is because the transaction is not performed physically but only uses electronic media. Contract of electronic transaction cannot be considered valid because it is difficult to see the competence of parties due to the absence of physical meeting. 
Therefore, one party can fill a cancellation in court in order to null a contract when the element of competency was not fulfilled. ${ }^{31}$

\section{b. Types of defaults}

Default in e-commerce has a wide range of types. On buyer's side, for instance, there is a delayed payment, an unrealized payment, and an incompliant payment. On seller's side, default happens when seller does not deliver goods, deliver unsuitable goods, and deliver goods lately (either on purpose or due to force majeur). Subekti states that default can be in four types: (1) party does not accomplish what was promised; (2) party accomplishes promise but is not appropriate; (3) party accomplishes what was promised but late; and (4) party accomplishes something that, according to the agreement, should not be acomplished. $^{32}$

\section{c. Validity of electronic data or documents}

Validity of electronic data or documents can also be a problem in terms of the utilization of e-commerce. Article 5, in conjunction with Article 6 of the EIT Law, regulate the process of verifying electronic data or documents -for instance, photos or recordings in an electronic device that are doubted. A document is considered valid as long as the information contained in it can be accessed, displayed, guaranteed, and accounted.

\section{Dispute Resolution in Electronic Transaction Contract}

In a transaction agreement that has not yet agreed on a dispute resolution method, the parties must later agree to choose one method of dispute resolutions by, for example, choosing a litigation or non-litigation method. No one wants a dispute with another person, including in business activities. If this happens, the parties, may it be right or wrong, can suffer certain losses. However, disputes are sometimes unavoidable. $^{33}$

Article 23 of the Consumer Protection Law mentions that if either manufacturer or distributor refuses and/or gives no response and/or even gives no compensation to their consumers, the consumers have a right to sue them and settle the dispute through Department of Consumer Dispute Settlement (BPSK -Badan Penyelesaian Sengketa Konsumen), or through litigation in local court. This is in line with Article 45 of the Consumer Protection Law as follows:

"(1) Every consumer who has suffered losses can sue business actor through an institution that is tasked to resolve disputes between consumers and business actors or through a local court.

(2) Settlement of consumer disputes can be pursued in court or nonlitigation based on the voluntary choice of the disputing parties.

\footnotetext{
31 Nanin Koeswidi Astuti, "Analisa Yuridis Tentang Perjanjian Dinyatakan Batal Demi Hukum", Jurnal Hukum tô-râ, Vol. 2 No. 1, 2016, p. 280.

32 Subekti, op.cit., p. 1.

33 Ibid., p. 143.
} 
(3) The settlement of disputes non-litigation as referred to in number (2) does not eliminate criminal responsibility as regulated in law.

(4) If a consumer dispute attempt has been selected non-litigation of law, it can only be pursued if the effort is declared unsuccessful by one of parties or by disputing parties."

In fact, Article 47 recognizes the settlement of disputes non-litigation. Article 45 mentions a special institution as an out-court settlement. Article 47 of the Consumer Protection Law states that

"Settlement of consumer disputes non-litigation is carried out to reach agreement on the form and amount of compensation and/or on certain actions to ensure that losses suffered by consumers will not occur again or will not be repeated." ${ }^{34}$

Amicable settlement of disputes may not work; and business actors can violate consumer rights. Thus, the Decree of the Minister of Industry and Trade of the Republic of Indonesia Number 350/MPP/Kep/12/2001 on the Implementation of Duties and Authorities of the Consumer Dispute Resolution Agency regulates the following.

\section{a. Conciliation}

Article 1 point 9 explains that conciliation is a process of resolving disputes nonlitigation with the BPSK intermediaries to bring together the disputing parties and the resolution depends on the parties. Consumers and business actors under the supervision of the Assembly in the process carry out this type of settlement. The Assembly seeks to reconcile the disputing parties and explain the laws and regulations in the field of consumer protection. Disputing consumers and business actors are given the same opportunity to explain the disputed matters.

\section{b. Mediation}

Article 1 paragraph 10 explains that mediation is a process of resolving consumer disputes non-litigation with the BPSK as an advisor and the settlement is left to the parties, namely consumers and business actors. Consumers and business actors, accompanied by an active assembly, carry out this type of settlement. The Assembly acts as a Mediator by providing advice, suggestions, and other relevant efforts to resolve disputes. However, the dispute resolution is still fully up to consumer and business actor in dispute. The resolution is stated in a written agreement between the parties to the dispute. Settlement of disputes by mediation and conciliation fully depends on the disputing parties to obtain agreement determining both the form and the amount of compensation received by consumers. This agreement is set forth in a written agreement signed by both parties. The BPSK subsequently makes minutes based on the settlement.

34 Janus Sidabalok, Hukum Perlindungan Konsumen di Indonesia, Bandung: Citra Aditya Bakti, 2006, p. 144. 


\section{c. Arbitration}

Another way of conciliation based on Article 1 is arbitration. Consumers and business actors in dispute fully trust the settlement to the BPSK in a settlement process. Arbitration has different implementation than conciliation or mediation. The Assembly acts actively to reconcile the disputing parties if no agreement is reached. What is done for the first time is to provide an explanation to consumers and business actors in dispute regarding the laws and regulations in the field of consumer's protection. Both consumers and business actors have equal opportunities to explain the matters in dispute. In this way, the decision is fully under the authority of the council formed by the BPSK.

In an effort to resolve consumer disputes, there are three options as follows.

1) An institution in charge of resolving disputes between consumers and business actors (in this case the BPSK).

2) The judiciary within the general court.

3) Out of court dispute settlement (conciliation, mediation, or arbitration)

\section{Conclusion}

Agreement in e-commerce equals to original sale and purchase agreement because of the arrangement of subject, object, and principal rights and obligations of parties. Legal relationship that is contained in an electronic contract is a legal relationship that is generated from the contract. Consequently, analogously, the contract law arrangement, according to the BW, can be enforced as a general law rule (lex generalis) for electronics. Both e-commerce and conventional transactions have in common process of bidding, receiving offers (purchases), payment, and delivery of goods.

The liability of parties to agreement in e-commerce lies only on seller and buyer. Marketplace, which is only a means or forum of seller and buyer, regulates both seller's and buyer's obligations and rights. If one of the obligations is violated, the relevant party can be legally sued. The difficulty of seeing party's competence in ecommerce is because both seller and buyer do not meet physically. Therefore, contract can be canceled through someone who submits a cancellation in court.

Dissimilar to an ordinary business transaction, e-commerce requires dispute settlement that is fast, cheap, and does not need unnecessary formalities. In essential, dispute resolution can be classified into certain categories. The first is amicable dispute settlement, a type of settlement by way of deliberate agreement, which consist of negotiation, mediation, and conciliation. The other type of dispute settlement is adversarial system, which consists of litigation or arbitration. The dispute settlement processes that are compatible to the philosophy of e-commerce are negotiation, mediation, conciliation, and arbitration (including online arbitration). 


\section{References}

\section{Books}

Agus Yudha Hernoko, Hukum Perjanjian Asas Proporsionalitas dalam Kontrak Komersial, Kencana Prenadamedia Group, Jakarta, 2014.

Celina Tri Siwi Kristiyanti, Hukum Perlindungan Konsumen, Sinar Grafika, Jakarta, 2009.

Dikdik M. Arief Mansur and Elisatris Gultom, Cyber Law (Aspek Hukum Teknologi Informasi), Refika Aditama, Bandung, 2005.

Edmon Makarim, Pengantar Hukum Telematika: Suatu Kompilasi Kajian, Raja Grafindo Persada, Jakarta, 2005.

Garner, Bryan A., Black's Law Dictionary, 10th Edition, Thomson Reuters, St. PaulMinnessota, 2014.

Hasanuddin Rahman, Contract Drafting Seri Keterampilan Merancang Kontrak Bisnis, Citra Aditya Bakti, Bandung, 2003.

Janus Sidabalok, Hukum Perlindungan Konsumen di Indonesia, Citra Aditya Bakti, Bandung, 2006.

Laudon, Kenneth C., and Jane P. Laudon, Management Information Systems: Managing the Digital Firm, 11th Edition, Pearson Education Limited, Edinburgh Gate, 2010.

Mariam Darus Badrulzaman, Aneka Hukum Bisnis, Revised Edition, Alumni, Bandung 2014.

Bandung, 2001.

Kompilasi Hukum Perikatan, Citra Aditya Bakti,

Mudakir Iskandar Syah, Hukum Bisnis Online Era Digital, Campustaka, Jakarta, 2018.

Muhammad Syaifuddin, Hukum Kontrak, Mandar Maju, Bandung, 2012.

Peter Mahmud Marzuki, Pengantar Ilmu Hukum, Kencana Prenada Media, Jakarta 2008.

Subekti, Hukum Perjanjian, Intermasa, Jakarta, 2014.

Sutan Remy Sjahdeini, Kebebasan Berkontrak dan Perlindungan yang Seimbang bagi Para Pihak dalam Perjanjian Kredit Bank di Indonesia, Pustaka Utama Grafiti, Jakarta, 2009.

Yahya Ahmad Zein, Kontrak Elektronik \& Penyelesaian Sengketa Bisnis E-Commerce, Mandar Maju, Bandung, 2009.

\section{Other Documents}

Agus Satory, "Perjanjian Baku dan Perlindungan Konsumen dalam Transaksi Bisnis Sektor Jasa Keuangan: Penerapan dan Implementasinya di Indonesia", Padjadjaran Jurnal Ilmu Hukum, Vol. 2, No. 2, 2015.

Enni Soerjati Priowirjanto, "Pengaturan Transaksi Elektronik dan Pelaksanaannya di Indonesia Dikaitkan dengan Perlindungan E-Konsumen", Padjadjaran Jurnal IImu Hukum, Vol. 1, No. 2, 2014. 
Gita "Klasifikasi Bisnis e-Commerce", https://supplychainindonesia.com/klasifikasi-bisnis-e-commerce/, accessed on September 2020.

Lintang Yudhantaka and Ninis Nugraheni, "The Concept of Authorization (Bezit) in Sales and Purchase Transactions of Virtual Property", Yustisia, Vol. 8, No. 1, 2019.

Mahir Pradana, "Klasifikasi Jenis-Jenis Bisnis E-Commerce di Indonesia", Jurnal Neobis, Vol. 9, No. 2, 2015.

Moh. Ali and Agus Yudha Hernoko, "Characteristics of Party Autonomy in a Transnational Electronic Consumer Contract", Yuridika, Vol. 35, No. 1, 2020.

Nanin Koeswidi Astuti, "Analisa Yuridis Tentang Perjanjian Dinyatakan Batal Demi Hukum", Jurnal Hukum tô-râ, Vol. 2 No. 1, 2016.

Rivki, "Kasus Jual-Beli Online Gambar Hard Disk, Ahli Hukum: Ada Unsur Menipu", https://news.detik.com/berita/d-4302473/kasus-jual-beli-online-gambar-harddisk-ahli-hukum-ada-unsur-menipu, accessed on October 2020.

Suwari Akhmaddhian and Asri Agustiwi, "Perlindungan Hukum Terhadap Konsumen dalam Transaksi Jual Beli Secara Elektronik di Indonesia", Jurnal Unifikasi, Vol. 3, No. 2, 2016.

\section{Legal Documents}

Indonesian Civil Code [Kitab Undang-Undang Hukum Perdata].

Law Number 1 of 1974 on Marriage [Undang-Undang Nomor 1 Tahun 1974 tentang Perkawinan].

Law Number 8 of 1999 on Consumer Protection [Undang-Undang Nomor 8 Tahun 1999 tentang Perlindungan Konsumen].

Law Number 11 of 2008 on the Electronic Information and Transactions [UndangUndang Nomor 11 Tahun 2008 tentang Informasi dan Transaksi Elektronik].

Law Number 19 of 2016 on Amendments to Law Number 11 of 2008 on the Electronic Information and Transactions [Undang-Undang Nomor 19 Tahun 2016 tentang Perubahan atas Undang-Undang Nomor 11 Tahun 2008 tentang Informasi dan Transaksi Elektronik].

Government Regulation Number 82 of 2012 on the Implementation of Electronic Systems and Transactions [Peraturan Pemerintah Nomor 82 Tahun 2012 tentang Penyelenggaraan Sistem dan Transaksi Elektronik].

Decree of the Minister of Industry and Trade of the Republic of Indonesia Number 350/MPP/Kep/12/2001 on the Implementation of Duties and Authorities of Consumer Dispute Resolution Bodies [Keputusan Menteri Perindustrian dan Perdagangan Republik Indonesia Nomor: 350/MPP/Kep/12/2001 tentang Pelaksanaan Tugas dan Wewenang Badan Penyelesaian Sengketa Konsumen]. 